\title{
Compositional analysis of excavated landfill samples and the determination of residual biogas potential of the organic fraction
}

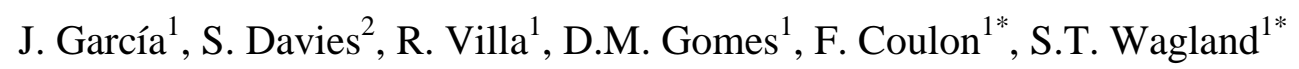

${ }^{1}$ School of Energy, Environment and Agrifood, Cranfield University, Cranfield, Bedfordshire, MK43 0AL, UK

${ }^{2}$ Viridor Waste management Ltd, Viridor House, Priory Bridge Road, Taunton, Somerset, TA1 1AP

* Corresponding authors: s.t.wagland@cranfield.ac.uk, Tel: +44 (0)1234 750111 ext 2404; f.coulon@cranfield.ac.uk Tel: +44 (0)1234 754981 


\begin{abstract}
The objectives of this study were to assess the biogas potential of landfilled materials and to further validate the suitability of the enzymatic hydrolysis test EHT as a valuable alternative to substitute the standardised test currently in use (BMP). Both tests were applied to a range of landfill waste samples. The waste composition and volatile solids content (VS) profile together with the BMP test results showed that the biogas potential of the waste samples was directly related to their VS content, as expected. The positive correlation between the VS and the BMP test $(r=0.67)$ suggests that the first could be used as a primary indicator of biogas potential of waste samples. Nevertheless, it should be validated against the BMP test because, occasionally, the VS content does not equate to the biogas production. This was mainly due to the paper content of the samples which also correlates positively $(\mathrm{r}=0.77)$ with the BMP biogas production. The EHT results showed a higher correlation with the BMP test $(r=0.91)$ than in previous studies which used a wider mixture of enzymes containing cellulase, hemicellulase and carbohydrase. This finding positions the EHT as a quick assessing method for the biodegradability of waste samples in future sample regimes.
\end{abstract}

Keywords: Biochemical methane potential, enzymatic hydrolysis test, landfill, biodegradation, landfill mining. 


\section{Introduction}

Landfill disposal in the United Kingdom dominated as a method of managing municipal wastes in the past. However, this practice has declined since the introduction of the European Landfill Directive [LFD] (European Commission, 1999). As an example, in $2008,55 \%$ of the total municipal solid waste (MSW) was still directly landfilled (Laner et al., 2012). In 2014, this was reduced to $28 \%$ (Eurostat, 2015). After the LFD, the EU Waste Framework Directive 2008/98/EC was implemented to prioritise waste management practices. This directive contributed to minimise waste disposal on landfills and increase the reuse, recycling and recovery of waste (European Commission, 2008).

Soon after waste is deposited, landfill gas [LFG] production commences, progressing through a number of biochemical stages (Christensen et al., 2001; Emkes et al., 2015; Kjeldsen et al., 2002). LFG consists mainly of methane $(45-60 \%)$ and carbon dioxide (40-60\%) (Barlaz et al., 1990; Emkes et al., 2015; Harrison et al., 2000; Kjeldsen et al., 2002). LFG's harmful impacts on the environment are well-known and are mainly due to its high greenhouse gas effect (Adu-Gyamfi et al., 2009, Donovan et al., 2011).

LFD requires operators to capture and treat landfill gas. This has directly decreased the number of MSW operating sites in the UK with a Landfill Directive Compliance permit, from 2,000 sites in April 2000 to 465 in 2009 (EA, 2013). Modern engineered landfill sites mechanically compact the waste to eliminate voids and seal them with low impermeability capping layers, usually clay (Environmental Change Institute, 2013). These landfill sites have gas capture systems which enable the collection of methanerich LFG that can be used to produce electricity. Landfills accepting untreated MSW 
with high content of biodegradable waste have a high potential of producing large amounts of LFG. The high calorific content of methane allows LFG to be recovered and used to produce a renewable source of energy (Emkes et al., 2015; Krook et al., 2012). Electricity production from landfill sites is an important source of renewable energy (Qasaimeh et al., 2016) in a time when European member states work towards their renewable energy targets (European Commission, 2009). Thus, converting this gas into energy and selling it to the grid is the main source of revenue for landfill sites (Donovan et al., 2011).

LFG production can be estimated by mathematical modelling. Commercial models such as LandGem of US-EPA, GasSim and the IPPCs landfill gas models have been developed to inform landfill site operators on LFG collection and its potential for energy conversion (Oonk, 2010). Currently, they rely on the amount of waste landfilled, its composition, the moisture content and landfill gas collection efficiency among other factors (Amini et al., 2012) assuming that landfills contain mostly biodegradable waste fraction. However recent studies showed that diversion of biodegradable municipal waste (BMW) from landfills considerably resulted in lower methane generation (Donovan 2010 and 2011). Thus the reliance of these LFG generation models on highly biodegradable waste fractions may have reduced their performance and increased their uncertainty (Raco, 2010, Scheutz, 2011). This, in turn contributes to the increment of the discrepancies between on-site LFG data performance and mathematical models estimations. Scheutz (2011) studied the amount of biogas obtained from sites treating different low organic waste streams using GasSim model. The author showed that GasSim largely overestimated the LFG production, especially for the landfill cells containing lower biodegradable waste content (LFG production measured on site 
ranging between $0.52-2.02 \mathrm{~kg} \mathrm{CH}_{4} / \mathrm{kg}$ waste/ day and GasSim prediction ranging between $27-83 \mathrm{~kg} \mathrm{CH} / \mathrm{kg}$ waste/day). The limitations of GasSim model when describing the organic content and biodegradability in different waste fractions were also highlighted (Scheutz et al., 2011). Thus, validation of these models against actual data is needed.

Considering this context, providing updated values on the biodegradable content of landfill waste would allow refining the sensitivity of the models. It would also provide landfill operators with better LFG production estimations. Moreover, this information could also help to establish possible issues with the landfill site that may lead to lower LFG production, or slower production rates (Emkes et al., 2015).

Several aerobic and anaerobic methods are currently available to assess the biodegradability of waste. The aerobic tests, such as the DR4 and ASTM are used to assess the stability of compost. The anaerobic tests include the GB21, GS90 and BM100 (Wagland et al., 2009). All methods have their own strengths and weaknesses. The aerobic tests offer a relatively short timescale for test completion (on average 4 days for DR4 and ASTM) but they do not measure the whole biodegradability. The anaerobic tests include the standardised BM100 currently used to assess the biodegradability of waste in protocol published by the Environment Agency [EA] for England and Wales. The BM100's weakness stems from its inconvenient routine testing which can last for more than 30 days. Thus, developing a rapid low cost method that can assess the biodegradability of waste with enough accuracy will be a highly valuable tool for the aforementioned monitoring purposes. 
Previously, an enzymatic hydrolysis test [EHT] method was investigated as a novel, rapid alternative to assess the biodegradability of waste (Wagland et al., 2011, 2008, 2007). This method considered that LFG is released mostly from the biodegradation of hemicellulose and cellulose materials. Results showed a good correlation between the EHT and the standardised biochemical methane potential [BMP] test when applied to a variety of organic waste samples $(r=0.77)$. These results position EHT as a good alternative to aerobic tests when assessing short term biodegradability of organic waste materials. The EHT method was also used by Chatelet (2012) to predict the residual biomethane potential (RBP) of anaerobic digestion (AD) digestate.

The objective was to assess the residual biogas potential of landfilled materials and to further validate the suitability of the EHT as a valuable alternative to the BMP protocol. A new range of enzyme mixture consisting of crude cellulase, crude hemicellulase, endocarbohydratase and lipase were used to assess waste biodegradability and residual biomethane potential.

\section{Materials and Methods}

\subsection{Origin of waste}

The waste samples analysed in this study were comprised of MSW from a landfill site, Site A, located in the South of England in the county of Sussex.

Site A is a closed site with its capping works completed in 2009. Between 2004 and 2006, the site received over a million tonnes of waste. Recently, gas wells were drilled and installed. 
Fourteen waste bags containing approximately between $2-5 \mathrm{~kg}$ were extracted at Site A. These were collected every $2 \mathrm{~m}$ until reaching the clay layer at $30 \mathrm{~m}$.

Table 1 shows the weight of the waste fractions collected at the different layers. >>>> Insert Table $1<<<<<<~$

Table 1. Waste fraction weight collected at landfill site A.

\subsection{Waste samples preparation and composition analysis}

Waste sample bags were stored in a cold room prior to manual sorting and analysis. Non-biodegradable waste including plastics, inert, and metals were removed by manual sorting. The weight of the collected fractions including fine organics, inert, wood, metal, textile paper/cardboard and plastic is shown in Table 1.

Dry matter (DM or TS) and volatile solids (VS) of the BMW samples were determined in triplicate following the procedure EN 12879:2000 (Wagland, 2008). This was done to calculate the amount of moisture present in the waste and the amount of volatile solids (VS). The samples were dried during 24 hours for the DM determination at $105{ }^{\circ} \mathrm{C}$ and 4 hours at $505^{\circ} \mathrm{C}$ for the VS determination.

According to Wagland (2008) there is not apparent benefit to reducing the particle size from $<10 \mathrm{~mm}$ to $<2 \mathrm{~mm}$ when undertaking the enzymatic hydrolysis test. Thus, in this study, the dried waste samples were shredded to a particle size of $8 \mathrm{~mm}$. Before shredding, the bulk of the waste samples were dried overnight. 


\subsection{Biochemical methane potential test (BMP)}

Different articles have been reported over the years to define a common BMP testing protocol (Angelidaki et al. 2009 and Raposo et al. 2011), the test in this work were carried out following the RBP protocol for the digestates (WRAP, 2011). In addition to waste samples analysed, control tests with samples containing inoculum (blanks) and a mixture of inoculum and cellulose (reference material) were all done in triplicate.

The reference material should be able to produce in excess of 0.5 litre of biogas per gram volatile solids (L/g VS) within the time of the test. The test was carried out in batch reactors of $1 \mathrm{~L}$. Sewage digestate from the local wastewater treatment plant was used as active inoculum. The BMP test was run for a minimum of 21 days or until biogas had reached a stable plateau (over 30 days for our samples). Biogas production was measured daily by water displacement and methane content using a SERVOPRO1400 CH4 gas analyser (Servomex, UK). The measurements were monitored daily during the first 7 days, and every 3 days after that.

$20 \mathrm{~g}$ of VS of each material, $350 \mathrm{~g}$ of inoculum, $1 \mathrm{~mL}$ of concentrated nutrient solution and water were added to $1 \mathrm{~L}$ batch reactors to a final volume of $800 \mathrm{ml}$. The bottles were sealed and the headspace flushed with nitrogen. The mixture was incubated under anaerobic conditions at $38^{\circ} \mathrm{C}$.

\subsubsection{Calculation of the biogas and methane production}

The amount of biogas produced was calculated considering both the area of the columns and also the conditions of the laboratory according to Walker (2010): 
$V_{s t p}=\frac{T_{s t p} \cdot A}{T_{a t m} \cdot P_{s t p}} \cdot\left[\left(P_{a t m}-P_{H_{2} O}-\rho \cdot g \cdot(H-h)\right) \cdot h\right]$

(Equation 1)

where, $\mathrm{V}_{\mathrm{stp}}=$ Volume of biogas (in standard conditions), $\mathrm{T}_{\mathrm{stp}}=$ Standard tempertature, $\mathrm{T}_{\mathrm{atm}}=$ Ambient temperature, $\mathrm{P}_{\mathrm{stp}}=$ Standard pressure, $\mathrm{P}_{\mathrm{atm}}=$ Ambient pressure, $\mathrm{P}_{\mathrm{H} 2 \mathrm{O}}=$ Pressure of the water, $\rho=$ density, $\mathrm{g}=$ gravity, $\mathrm{H}=$ distance from the bottom to the top of the column, $\mathrm{h}=$ void distance in the column.

The volume of biogas produced was divided by the total amount of VS solids added (coming from the substrate and the inoculum) and the biogas produced by the waste samples calculated by subtraction using the value produced by the blanks. This was done using the following equation:

Substrate Production (out of Inoculum)

$$
=V_{\text {stp }}-\left(\text { Inoc }_{\text {Prod }} \cdot V S_{\text {inoc }}\right) / V S_{\text {subs }}
$$

(Equation 2)

where, $\mathrm{V}_{\mathrm{stp}}=$ volume of biogas in standard conditions, Inoc $_{\text {prod }}=$ Biogas due to the inoculum, $\mathrm{VS}_{\text {inoc }}=$ volatile solids content of the inoculum, $\mathrm{VS}_{\text {subs }}=\mathrm{VS}$ content of the substrate.

Biogas production rate results were expressed in terms of L biogas/g VS added.

Methane production was then calculated considering the percentage of methane present in the biogas analysed ( $\mathrm{L} \mathrm{CH}_{4} / \mathrm{kg}$ VS added).

\subsection{Enzymatic hydrolysis test (EHT)}

As previously described by Wagland (2008), EHT consists of three main steps as shown in Figure 1. 


\section{>>> Insert Figure $1<<<<$}

\section{Figure 1. Schematic of the enzymatic hydrolysis test method}

Firstly, an equivalent waste sample of $3 \mathrm{~g}$ of VS was placed in $250 \mathrm{ml}$ glass bottles. 100 $\mathrm{ml}$ of $0.1 \mathrm{M} \mathrm{pH}$ buffer solution (containing citric acid and sodium phosphate) were then added to each bottle. Once settled, $5 \mathrm{ml}$ of sample were removed and filtered using 0.45 $\mu \mathrm{m}$ filters to remove the solids present in the liquid. The filtrate was analysed for soluble chemical oxygen demand (sCOD) in Spectroquant COD test tubes. The value obtained was recorded as Phase 1 oxygen demand.

Secondly, the sample mixture of the bottles was autoclaved at $121^{\circ} \mathrm{C}$ for 15 minutes to remove any biological activity. This procedure ensures that sCOD release after enzyme addition is due to enzyme hydrolysis of the sample (Wagland, 2008). Again, $5 \mathrm{ml}$ of sample was removed and filtered for sCOD analysis. The value obtained represents Phase 2 oxygen demand.

Finally, between $10-20 \mathrm{ml}$ of prepared enzyme solution were added to the sample mixture. All the bottles were placed in an incubator at $50{ }^{\circ} \mathrm{C}$ and shaken at different times. $5 \mathrm{ml}$ of sample were removed and filtered after $20 \mathrm{~h}$ of incubation for the Phase 3 sCOD analysis.

The amounts and the activity of the different enzyme mixtures tested are shown in Table 2. 
Table 2. Characteristics of the enzymatic mixtures used during the EHT test

The commercial enzymes had the following characteristics:

1. Sigma cellulase from Trichoderma viride $(6 \mathrm{U} / \mathrm{mg})$ contained of a mixture of crude cellulase and hemicellulase (Sigma, 2013a).

2. Sigma hemicellulase from Aspergillus Niger $(1.5 \mathrm{U} / \mathrm{mg})$ contained a mixture of glycolitic enzymes including xylanase (Sigma, 2013b).

3. Biocatalysts Depol $40 \mathrm{TM}$ contained a broad spectrum of carbohydrase containing enzymes: cellulase from Trichoderma sp (1.2 U/mg) and endogalacturonase from Aspergillus sp (0.8 U/mg) (Biocatalysts, 2013a).

4. Biocatalysts Lipomod 166 contained lipase/esterase from Mucor javanicus (5.22 U/mg) with preference for mid length (C18) fatty acid glycerol linkages (Biocatalysts, 2013b)

5. Sinobios Cel30 from Humicola insolens contained a crude cellulase (30 U/mg)

The benchmark test comprised the same enzymatic mixture used by Wagland (2008) (Enzymatic combination 1).

\subsubsection{Calculation of the equivalent methane production}

The COD data of phases 1, 2 and 3 was converted into dissolved organic carbon (DOC) first and then to L CH4/kg VS to assess if there was a correlation between the EHT and the BMP methods. Following the method by Wagland et al. (2008) the DOC was calculated and then converted into $\mathrm{mg} \mathrm{C} / \mathrm{kg}$ VS. This considered the volume change for each bottle after the COD analysis' extractions and the addition of the enzyme mixture. Finally, the concentrations in $\mathrm{mg} \mathrm{C} / \mathrm{kg}$ VS were converted into $\mathrm{L} \mathrm{CH}_{4} / \mathrm{kg}$ VS assuming 
a methane production of $350 \mathrm{ml}$ per g of sCOD (Lin et al., 1999, Rodrigo et al., 2011, Chatelet, 2012).

Further to this, methane production obtained with the EHT method was compared with those of the BMP test. The comparison allowed determining how the results correlated with each other. The Pearson's correlation coefficient (r) was assessed.

\section{Results and Discussion}

\subsection{Waste composition}

The overall composition is outlined in Table 1. A clear waste composition profile of the core waste sample from Site A was obtained after manually sorting the plastic, paper, textile, metal, wood, inert and the remaining fine organics (Figure 2).

\section{>>>> Insert Figure $2<<<<<$}

Figure 2. Waste composition profile on the drill log of Site A.

In all cases, there was a predominance of the biodegradable waste fraction that consisted of a mixture of fine organics, paper/cardboard, textile and wood. Figure 2 shows that the main fraction was composed of the organic fines fraction except at 18 and $24 \mathrm{~m}$ where paper/cardboard was predominant (with values of $52 \%$ and $37 \%$ respectively). This is in agreement with a previous study on the characterisation of excavated samples, which also observed a high percentage of fines (Quaghebeur et al. 2013). The top layers up to $4 \mathrm{~m}$ had large proportions of inert materials. This is expected as those layers usually contained material used for capping works and pebbles from the ground. Plastic 
percentage was important in the first layers between 4 and 8 meters with values close to $40 \%$ of the total waste. In contrast, the percentage of plastic dropped to $<20 \%$ in the other layers.

These results align with a study carried out by Defra (2008). Despite the heterogeneous nature of MSW (it comprises wastes from residential, urban, commercial and partly industrial areas) the organic matter usually constitutes the main fraction (Bigili et al., 2009). This was the predominant fraction in 535 kerbside datasets analysed (Defra, 2008). Plastic fraction, in general, was higher than the $10 \%$ estimated in the Defra's study (2008). However, this may depend on the waste disposal practices and on particular characteristics of Site A. Furthermore, it must be noticed that samples were obtained from the same drill log. Therefore, it is likely that the composition may change if other drill logs were collected.

After manual sorting, the BMW analysed consisted of fine organics, paper and textile. Wood was removed due to its lignin content and reduced biodegradability (Rodriguez et al., 2005, Raju et al., 2011, Wagland 2008).

\subsection{Dry matter and volatile solids content}

The VS profile obtained for Site A waste sample is shown in Figure 3.

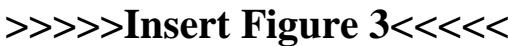

\section{Figure 3. Volatile solids content profile of Site A}

VS values of the waste fraction provide insight into the organic carbon content of the organic fraction. However, this parameter does not directly reflect the biodegradability 
of a sample material (Wagland, 2008). This is because the waste sample consists of a mixture of a broad spectrum of molecules with varying biodegradability. Some of them are easily degradable such as simple sugar and fats. Hemicellulose and cellulose are moderately degradable whereas lignin molecules are hardly degradable (Oonk, 2010).

Assuming that all carbon is amenable to biodegradation would result in an overestimation of the biodegradability of the sample. This said, several authors have stated that this parameter can give a gross idea of the biodegradability of the waste samples (Wagland, 2008, Scheviano, 2009, Raposo, 2011). Thus, the waste layers that have potential to produce higher biogas amounts are located at 8 and $16-18 \mathrm{~m}$ (Figure 3). In contrast, a lower potential should be expected from the layers located at $2-6$ and $20 \mathrm{~m}$.

\subsection{Biochemical methane potential (BMP)}

BMP involved the biodegradation of complex high molecular weight organic compounds. These compounds usually consist of fats, proteins, carbohydrates and lignin broken down into soluble polymers by hydrolytic fermentative bacteria. Figure 4 shows the cumulative biogas production over 31 days of incubation.

>>>>> Insert Figure $4<<<<$

Figure 4. Cumulative biogas production during 31 days of incubation ( $\mathrm{L}$ biogas/kg VS added) 
Results show different biodegradability on the waste samples depending on the layer considered. The biodegradability ranges from a lower biogas production of $38 \mathrm{~L}$ biogas/kg VS added to a higher value of $290 \mathrm{~L}$ biogas/kg VS. These values are within previous reported ranges. The BMP test carried by Wagland (2008) showed an average value of $300 \mathrm{~L}$ biogas $/ \mathrm{kg}$ VS added for a MSW input. The biogas yield of anaerobic digestion of organic fraction of municipal solid waste (OFMWS) values reported in the literature range between 60 - 530 1/kg VS added (Raposo et al., 2011).

Methane trend production is usually similar to that of biogas, being in general higher for samples that produce higher biogas amounts. The average percentage of methane produced by each waste sample during the BMP test is shown in Figure 5.

\section{>>> Insert Figure $5<<<<<$}

\section{Figure 5. Methane composition of the waste samples}

Methane percentage ranged between $20 \%$ and 50\%. The highest percentages were found between the middle $(12 \mathrm{~m})$ and the lower waste layers of the site $(24 \mathrm{~m})$. These are within the normal ranges of LFG that are theoretically comprised between $40-60 \%$ of methane. Lowest values were achieved at the top and the bottom layers

A positive correlation was obtained $(r=0.67)$ between VS content of the waste samples and the BMP biogas production. This is expected as VS content typically indicates a higher organic, and thus biodegradable, component. Samples that produced the lowest biogas amounts $(<100 \mathrm{~L}$ biogas/kg VS) have the lowest VS percentage on a dry basis (samples collected at 4, 12, and $20 \mathrm{~m}$ ). Conversely, the maximum biogas productions (> 
$200 \mathrm{~L}$ biogas/kg VS) were obtained for the samples which had higher proportions of VS (Samples collected at 8,16 and $24 \mathrm{~m}$ ).

This trend was not observed for the waste sample collected at $28 \mathrm{~m}$ despite having a relatively high VS content of $47 \%$. A positive correlation $(r=0.77)$ between the paper content of the samples and the BMP biogas results was also obtained. This is related to the paper content in the sample containing high amount of cellulose (Valorlux, 2013), easily degraded under anaerobic conditions.

However, different type of papers (cardboard, newsprint or office paper) will contain different levels of lignin and have different levels of biodegradability (82\% for office paper, $47 \%$ cardboard and $22 \%$ for newsprint) which will hinder the process and reduce the amount of biogas and methane produced (Cornell, 2001). This is probably the case for samples at $8 \mathrm{~m}$ and $14 \mathrm{~m}$.

All this suggests that VS can be used as a gross indicator of the biogas potential. However, caution is needed. The total VS content of a waste sample is not bioavailable for degradation and the percentage of paper is likely to influence gas production.

Further to this, BMP is designed to provide ideal digestion conditions and thus providing a maximum biogas production and methane yields (Rodrigo et al., 2011). In contrast, on-site real anaerobic degradation of landfill waste is a very slow process affected by several parameters. These parameters include the age and composition of waste, its moisture content, the geology of the site, the leachate level, the temperature, the distribution of waste within the landfill and the effectiveness of capping of the site (Bilgili et al., 2009). 
Therefore, caution is also needed in extrapolating BMP test results, as it would be highly unlikely to obtain similar biogas production on-site. Within the available measures, landfill bioreactor technology has proved to be an effective method in enhancing the biogas production of landfill. This includes using physical (shredding of the waste), chemical (leachate recirculation, $\mathrm{pH}$ adjustment, addition of nutrients and buffers etc.) or biological processes in different types of landfill bioreactor (aerobic, anaerobic, hybrid) (Karthikeyan et al., 2009).

\subsection{Enzymatic hydrolysis test}

Previous studies reported that the combination of cellulase and hemicellulase enzyme increased significantly the hydrolysis yield of substrates (Rodriguez, 2005). Following this, Wagland (2008) investigated the enzymatic hydrolysis of 11 waste samples using a mixture of crude cellulase and hemicellulase enzymes. A correlation $(r=0.77)$ between the EHT and the BMP was observed. This indicates that an enzymatic test has the potential to assess the biodegradability of waste. The best correlation identified was between the DOC released between Phases 2 and 3 and the enzymatic activity of the enzyme tested (Wagland, 2008). Values ranged between 20000 and $60000 \mathrm{mg} \mathrm{C} / \mathrm{kg} \mathrm{VS}$ of DOC released for that test.

The performance of all enzyme mixtures tested in this study is summarised in Figure 6.

>>>> Insert Figure $6<<<<<$

Figure 6. DOC released between Phase 3 and Phase 2 according to the enzyme combination used (mg C/kg VS). 
Results clearly show higher DOC release for enzymatic combinations 4, 5 and 6. Adding carbohydrase and lipase activity to the cellulase and hemicellulase activity releases more DOC. This may be because a wider range of hydrolysable compounds is covered by these enzymatic combinations (Table 2). This observation is partially supported by the correlations observed between the VS of the samples and the DOC release. Correlation between enzymatic combinations $1-3,5$ and 6 is positive $(r<0.35)$ however for enzymatic combination 4 the correlation suggests a stronger relationship ( $\mathrm{r}$ $=0.64)$.

The benchmark test using crude cellulase and hemicellulase (enzymatic combination) similar to the one used in Wagland (2008), provided the lowest DOC release values (Figure 6). Overall these were $>20000$ units lower than the values obtained with the combinations 4, 5 and 6. Furthermore, there were some specific samples in which the hydrolysis of the waste did occur or was negligible (samples collected at 4 and $24 \mathrm{~m}$ at Site A Figure 6). This is surprising, as Wagland (2008) obtained a good performance using this enzymatic combination with 11 different MSW samples. Further to this, there were no apparent benefits for using the Sinobios crude cellulase (Figure 6). This low DOC release (enzymatic combination 1 and 3) may be due to the fact that the EHT was not able to completely hydrolyse the cellulose present on these samples.

A composition analysis of different municipal solid waste samples done by Wagland (2008) yielded different results. The study reported that four different MSW samples had 15 and $33 \%$ of cellulose and hemicellulose. Furthermore, there were other important fractions present in the waste such as proteins, carbohydrates and lipids. 
Biogas formation in landfill sites is mainly due to biodegradation of cellulose and hemicellulose. Nevertheless, proteins, carbohydrates and lipids are degraded under anaerobic conditions. Thus, it is likely that the waste samples analysed in this study may have these components in addition to cellulose and hemicellulose.

The variations observed between the different waste samples may highly relate to the specific composition of the waste samples. Therefore, a compositional analysis of the waste samples in terms of lipids, proteins, carbohydrates, cellulose, hemicellulose and lignin could be useful. This analysis will help understand the particular performances of the different enzymatic combinations in each sample and the differences between both.

\subsection{Comparison of BMP and EHT}

Comparing the amount of methane obtained with both methods showed that EHT performs similarly to the BMP test. For example, the enzymatic combination 4 gave a higher methane production when BMP test produced the highest methane content (Figure 7).

However, the EHT tends to underestimate the methane production compared to the BMP test. This was especially significant for the samples having the highest amount of biodegradables (Figure 7).

>>>>Insert Figure $7<<<<<$

Figure 7. BMP and EHT methane production values ( $\left.\mathrm{L} \mathrm{CH}_{4} / \mathrm{kg} \mathrm{VS}\right)$ 
In contrast, the EHT results were relatively similar to the BMP test for the less biodegradable waste samples (collected at 4, 12 and $20 \mathrm{~m}$ ). Although the values were similar for the enzymatic combination 5 with the BMP test, there was still an underestimation in the case of the enzymatic combination 4 (methane production values were contained within $30-50 \%$ of similarity with the BMP test) (Figure 7).

The differences between the EHT and BMP results come from the influence of waste composition in both methods, especially the paper content. The BMP test favoured its biodegradation whilst the EHT method did not. This can explain the lower methane production for the samples containing high paper content (samples collected at 16 and $24 \mathrm{~m})$. Additionally, the enzymatic combinations 1 and 3 obtained low values of methane. All of this supports the fact that EHT was not able to completely hydrolyse the cellulose present in the waste samples.

A significant difference was also observed for the waste sample collected at $8 \mathrm{~m}$. This difference suggests that high VS content (65\% on a dry basis) may also influence the performance of the EHT.

There was a high positive correlation between the enzymatic combination 4 and the BMP test results, with $r=0.92$. This value was higher to the previous correlation reported by Wagland (2008) and highlights the potential of this enzymatic mixture. A correlation of $r=1.00$ is not expected due to the differences between both methods. BMP favours anaerobic conditions for optimal biodegradation of waste samples whereas the enzymatic test measures the biodegradation of cellulose, hemicellulose, lipids and proteins done by the enzymes in the specific conditions of the test. 


\section{Conclusions}

Overall this study provides new evidences that there is potential to use the EHT as an alternative and quick method to assess the biodegradability of waste. Generally, the EHT tends to perform similarly to the BMP test, giving higher methane amounts when the BMP test does. However, there is a general trend to underestimate the methane production. This was especially significant for the most biodegradable samples. The underestimation of methane production was linked to the VS and paper content of the samples. This finding was explained by the fact that EHT cannot accomplish the total hydrolysis of the material that is biodegraded in the BMP test with high VS content. The opposite phenomenon was observed for the BMP test. This suggests that VS content of the samples could be only used as a preliminary indicator of the biodegradability of the waste samples. This study assessed different enzymatic combinations, with one such combination yielding a higher correlation of the EHT with the BMP test $(r=0.91)$ than in previous studies. This finding further improves the EHT method and supports the use of the EHT as a quick assessing method for the biodegradability of waste samples.

. Further studies should focus on the analysis of the tests performance with an exactly known composition (raw and chemical) of substrates. The percentage of raw composition (textile, wood, paper/cardboard, fine organics, metals, inert etc.) and chemical composition (cellulose, hemicellulose, carbohydrates, proteins, lipids and lignin content) of the substrates' should be varied. It will help to better assess specific issues concerning to enzymatic performance. By doing so, it is likely that correlation 
factors could be obtained between the EHT and the BMP test. This will also allow validating the EHT and positioning it as an alternative to the BMP essay.

\section{References}

Adu-Gyamfi K.A., Villa R., Coulon F. 2010. Renewable Energy, Landfill Gas and Energy from Waste: Now, Next and Future. Communications in Wastes and Resource Management. 10: 4-12 http://www.ciwm.co.uk/mediastore/FILES/18544.pdf.

Angelidaki, M., Alves, D., Bolzonella, L., Borzacconi, J. L., Campos, A. J., Guwi S., Kalyuzhnyi, P., Jenicek J. and van Lier B. (2009) Defining the biomethane potential (BMP) of solid organic wastes and energy crops: a proposed protocol for batch assays. Water. Sci. Technol. 59, 927-934.

ATDSR, (2001), Landfill gas basics, available at: http://www.atsdr.cdc.gov/HAC/landfill/PDFs/Landfill_2001_ch2mod.pdf/ (Accessed on $31^{\text {th }}$ May).

Barlaz, M.A., Ham, R.K., Schaefer, D.M., 1990. Methane production from municipal refuse: A review of enhancement techniques and microbial dynamics. Crit. Rev. Environ. Control 19, 557-584.

BERR (2008), UK Energy in Brief July 2008, available at: http://webarchive.nationalarchives.gov.uk/+/http://www.berr.gov.uk/files/file4698 3.pdf/ (Accessed on $23^{\text {th }}$ May).

Bilgili, M.S., Demir, A. and Varank, G., (2009), Evaluation and modeling of biochemical methane potential (BMP) of landfilled solid waste: A pilot scale study.

Biocatalysts

(2013a),

Depol $^{\mathrm{TM}}$

40 ,

available

at: http://www.innovadex.com/documents/1116137.pdf?bs=4817\&b=188146\&st=20/ (Accessed on $1^{\text {st }}$ August). 
Biocatalysts (2013a), LIPOMOD $^{\mathrm{TM}}$ 166P, available at: http://www.innovadex.com/documents/1116128.pdf?bs=4817\&b=188137\&st=20/ (Accessed on $1^{\text {st }}$ August).

BIS (2012), UK Energy in Brief 2012, available at: https://www.gov.uk/government/uploads/system/uploads/attachment_data/file/658 98/5942-uk-energy-in-brief-2012.pdf/ (Accessed on $23^{\text {th }}$ May).

Chatelet, A. (2012), Enzymatic hydrolysis test method as an alternative to assess the residual biogas potential of digestate, Cranfield University, Cranfield.

Christensen, T.H., Kjeldsen, P., Bjerg, P.L., Jensen, D.L., Christensen, J.B., Baun, A., Albrechtsen, H.J., Heron, G., 2001. Biogeochemistry of landfill leachate plumes. Appl. Geochemistry 16, 659-718.

Defra (2006), A beginners guide to the landfill allowance trading Scheme (LATS), available at: http://archive.defra.gov.uk/environment/waste/documents/latsbeginners-guide.pdf/ (Accessed on $27^{\text {th }}$ May).

Defra (2008), Municipal solid waste composition: Review of municipal waste components analyses - WR0119, available at: http://randd.defra.gov.uk/Default.aspx?Module=More\&Location=None\&ProjectI $\mathrm{D}=15133 /$ (Accessed on $24^{\text {th }}$ August)

Defra (2010a), Environmental Permitting Guidance, The Landfill Directive, For the Environmental Permitting (England and Wales), available at: http://www.defra.gov.uk/publications/files/pb13563-landfill-directive-100322.pdf/ (accessed on $24^{\text {th }}$ May).

Defra (2010b), Consultation on meeting EU Landfill Diversion targets, available at: available at: http://webarchive.nationalarchives.gov.uk/20080305115859/http:/www.defra.gov. uk/corporate/consult/landfill-diversion/index.htm/ (Accessed on 12 $2^{\text {th }} \mathrm{June}$ )

Defra (2010c), Consultation on the introduction of restrictions on the landfilling of certain wastes, available at: https://web5.hullcc.gov.uk/akshull/images/att15531.pdf/ (Accessed on 12 ${ }^{\text {th }}$ June). 
Defra (2010d), UK meets 2010 Landfill Directive target and responds to landfill consultations, available at: https://www.gov.uk/government/news/uk-meets-2010landfill-directive-target- and-responds-to-landfill-consultations/ (Accessed on $10^{\text {th }}$ June).

Donovan, S. M., Bateson, T., Gronow, J.R. and Voulvoulis, N. (2010), Modelling the behavior of mechanical biological treatment outputs in landfills using the GasSim model, Science of the Total Environment, vol.408, no.8, pp.1979-1984.

Donovan, S. M., Pan, J., Bateson, T., Gronow, J. R. and Voulvoulis, N. (2011), Gas emissions from biodegradable waste in United Kingdom landfills, Waste Management and Research, vol. 29, no. 1, pp. 69-76.

Environment Agency, (2005), Guidance on monitoring MBT and other pretreatment processes for the landfill allowances schemes (England and Wales).

Environment Agency, EA, (2009), Guidance on monitoring of MBT and other treatment processes for the landfill allowances schemes (LATS and LAS) for England and Wales, available at: http://a0768b4a8a31e106d8b050dc802554eb38a24458b98ff72d550b.r19.cf3.rackcdn.com/scho1009breb-ee.pdf/ (Accessed on $12^{\text {th }}$ June).

Environment Agency, EA, (2011), Treatment of Waste for Landfill, available at: http://www.znrfak.ni.ac.rs/SRB/10-Studije/10-01OAS/PREDMETI/KOMUNALNI\%20SISTEMI\%20I\%20ZIVOTNA\%20SREDI NA/NASTAVNI\%20MATERIJALI/LITERATURA/SEMINARSKI\%20159\%20 do\%20\%20162.pdf/ (accessed on 30 ${ }^{\text {th }}$ May).

Environment Agency, EA, (2013), Regulating Landfills, available at: http://www.environment-agency.gov.uk/business/sectors/32445.aspx/ (Accessed on $10^{\text {th }}$ June).

Environmental Change Institute (ECI) (2013), Waste and landfill - chapter 05, available at: http://www.eci.ox.ac.uk/research/energy/downloads/methaneuk/chapter05.pdf/ (Accessed on $27^{\text {th }}$ August 2014).

Emkes, H., Coulon, F., Wagland, S., 2015. A decision support tool for landfill methane 
generation and gas collection. Waste Manag. 43, 307-318. doi:10.1016/j.wasman.2015.07.003

Eurostat, 2015. No Title [WWW Document]. Munic. waste Stat. URL http://ec.europa.eu/eurostat/tgm/refreshTableAction.do?tab=table\&plugin=1\&pcod $\mathrm{e}=$ tsdpc240\&language $=\mathrm{en}$

European Commission (1999), Council Directive 1999/31/EC of 26 April 1999 on the landfill of waste, Office for Official Publications of the European Communities, Luxembourg.

European Commission (2008), Directive 2008/98/EC of the European Parliament and of the Council of 19 November 2008 on waste and repealing certain Directives, Office for Official Publications of the European Communities, Luxembourg.

European Commission (2009), Directive 2009/28/EC of the European Parliament and of the Council of 23 April 2009 on the promotion of the use of energy from renewable sources and amending and subsequently repealing certain Directives, Office for Official Publications of the European Communities, Luxembourg.

Fastblep (2013), Types of enzyme - biochemistry, available at: http://www.fastbleep.com/biology-notes/40/116/1159 (Accessed on $5^{\text {th }}$ August)

Godley, A., Lewin, K., Frederickson, J., Smith, R. and Backley, N. (2007), Application of BM100 Biodegradability tests to treated and untreated organic wastes, Proceedings Sardinia, Eleventh International Waste Management and Landfill Symposium, S. Margherita di Paula, Cagliari, Italy.

Godley, A. R., Lewin, K., Graham, A., Barker, H. and Smith, R. (2004). Biodegradability determination of municipal waste: an evaluation of methods. Waste 2004- Integrated Waste Management and Pollution Control: Policy and Practice, Research and Solutions, Stratford-upon-Avon, UK.

Harrison, K.W., Dumas, R.D., Barlaz, M.A., Nishtala, S.R., 2000. A life-cycle inventory model of municipal solid waste combustion. J. Air Waste Manag. Assoc. 50, 993-1003. 
Karthikeyan, O.P. and Kurina, J., (2004), Bioreactor landfills for sustainable solid waste management, available at: http://www.swlf.ait.ac.th/UpdData/National/BIOREACTOR\%20LANDFILLS\%2 0FOR\%20SUSTAINABLE\%20SOLID\%20WASTE\%20MANAGEMENT.pdf/ (Accessed on $27^{\text {th }}$ August).

Kjeldsen, P., Barlaz, M.A., Rooker, A.P., Baun, A., Ledin, A., Christensen, T.H., 2002. Present and Long-Term Composition of MSW Landfill Leachate: A Review. Crit. Rev. Environ. Sci. Technol. 32, 297-336.

Krook, J., Svensson, N., Eklund, M., 2012. Landfill mining: A critical review of two decades of research. Waste Manag. 32, 513-520. doi:10.1016/j.wasman.2011.10.015

Laner, D., Crest, M., Scharff, H., Morris, J. W. F. and Barlaz, M. A. (2012), A review of approaches for the long-term management of municipal solid waste landfills, Waste Management, vol. 32, no. 3, pp. 498-512.

Mathbits (2013), Correlation coefficient, available at: http://mathbits.com/MathBits/TISection/Statistics2/correlation.htm/ (Accessed on $30^{\text {th }}$ August).

Nastev, M., Therrien, R., Lefebvre, R. and Gélinas, P. (2001), Gas production and migration in landfills and geological materials, Journal of contaminant hydrology, vol. 52, no. $1-4$, pp. 187-211.

Oonk, H., (2010), Literature review methane from landfills, methods to quantify generation, oxidation and emission, available at: http://www.sustainablelandfillfoundation.eu/documenten/Landfill\%20general/100 520\%20Final\%20report\%20\%20review\%20landfill\%20methane\%20SLF.pdf/ (Accessed on $24^{\text {th }}$ August)

Qasaimeh, A., Abdallah/Q, M.R., Hani, F.B., 2016. A Review on Biogas Interception Processes in Municipal Landfill. J. Environ. Sci. Technol. 9, 1-25. doi:10.3923/jest.2016.1.25

Quaghebeur, M., Laenen, B., Geysen, D., Nielsen, P., Pontikes, Y., Van Gerven, T., 
Spooren, J., 2013. Characterization of landfilled materials: screening of the enhanced landfill mining potential. J. Clean. Prod. 55, 72-83. doi:10.1016/j.jclepro.2012.06.012

Raco, B., Battaglini, R. and Lelli, M., (2010), Gas emission into the atmosphere from controlled landfills: an example from Legoli landfill (Tuscany, Italy).

Raju, L.A., Angenent, L.T. and Scott, N.R., (2011), Biochemical methane potential and biodegradability of complex organic substrates.

Raposo F., De la Rubbia M.R., Fernandez-Cegri, V., Borja, R., 2011. Anaerobic digestion of solid organic substrates in batch mode: An overview relating to methane yields and experimental procedures. Renew Sust Energy Rev. 16. 861877.

Rodriguez, C., Hiligsmann, S, Ongena, M., Thonart, P. and Charlier, R., ( 2005), Development of an enzymatic assay for the determination of cellulose bioavailability in municipal solid waste.

Scheutz, C., Fredenslund, A.M., Nedenskov, J., Samuelsson, J. and Kjeldsen, P. (2011), Gas production, composition and emission at a modern disposal site receiving waste with a low-organic content, Elsevier Ltd.

Schievano, A., Scaglia, B., Giuliana D.I., Malagutti, L., Gozzi, A. and Adani, F., (2009), Prediction of biogas potentials using quick laboratory analyses: Upgrading previous models for application to heterogeneous organic matrices, Elsevier Ltd.

Séverin, M., Velis, C. A., Longhurst, P. J. and Pollard, S. J. T. (2010), The biogenic content of process streams from mechanical-biological treatment plants producing solid recovered fuel. Do the manual sorting and selective dissolution determination methods correlate?,Waste Management, vol. 30, no. 7, pp. 11711182.

Siddiqui, A. A., Richards, D. J. and Powrie, W. (2012), Investigations into the landfill behaviour of pretreated wastes, Waste Management, vol. 32, no. 7, pp. 14201426. 
Sigma (2013a), Cellulase from trichoderma viride, avaialbe at: http://www.sigmaaldrich.com/catalog/product/sigma/c9422?lang=en\&region=GB/ (Aaccessed on $1^{\text {st }}$ August).

Sigma (2013b), Hemicellulase from Aspergillus Niger, available at: http://www.sigmaaldrich.com/catalog/product/sigma/c9422?lang=en\&region=GB/ (Aaccessed on $1^{\text {st }}$ August).

UK Government (2013a), The Waste and Emission Trading Act 2003, available at: http://www.legislation.gov.uk/uksi/2013/141/made/ (Accessed on 12th June).

UK Government (2013b) , Norlands lane - Surrey County Council, available at: http://mycouncil.surreycc.gov.uk/mgConvert2PDF.aspx?ID=3588/ (Accessed on $29^{\text {th }}$ August).

USC, University science books (2013), Enzyme kinetics, available at: http://www.uscibooks.com/changten.pdf/ (Accessed on $4^{\text {th }}$ August).

Valorlux (2013), Paperboard, available at: http://valorlux.lu/sites/valorlux/files/fabrication-recyclage_papier-carton_en.pdf/ (Accessed on $30^{\text {th }}$ August).

Velis, C. A., Longhurst, P. J., Drew, G. H., Smith, R. and Pollard, S. J. T. (2010), Production and quality assurance of solid recovered fuels using mechanicalbiological treatment (MBT) of waste: A comprehensive assessment, Critical Reviews in Environmental Science and Technology, vol. 40, no. 12, pp. 9791105.

Viridor (2013), Viridor gas modeling, Excel source.

Wagland, S.T., Smith, R., Godley, A.R., Tyrrel, S.F. and Blakey, N. (2007), Development and application of an enzymatic hydrolysis test to assess the biodegradability of organic waste material, Cranfield University, Cranfield.

Wagland, S. T. (2008), Development and evaluation of a rapid enzymatic hydrolysis test method to assess the biodegradability of organic waste, Cranfield University, Cranfield. 
Wagland, S.T., Godley, A.R., Frederickson, J., Tyrrel, S.F., Smith, R., 2008. Comparison of a novel enzymatic biodegradability test method with microbial degradation methods. Commun. Waste Resour. Manag. 9, 80-86.

Wagland S.T., Tyrrel, S.F., Godley, A.F. and Smith, R. ( 2009), Test methods to aid in the evaluation of the diversion of biodegradable municipal waste (BMW) from landfill, Elsevier Ltd.

Wagland, S.T., Godley, A.R., Tyrrel, S.F., 2011. Investigation of the application of an enzyme-based biodegradability test method to a municipal solid waste biodrying process. Waste Manag. 31, 1467-1471.

Wagland, S.T., Tyrrel, S.F., Godley, A.R., Smith, R., Blakey, N., 2007. Development and application of an enzymatic hydrolysis test to assess the biodegradability of organic waste material. Proc. Sardinia 2007, Elev. Int. Waste Manag. Landfill Symp.

Walker, M., Banks, C., Heaven, S., Frederickson, J. (2010), Residual biogas potential test for digestates, available at: http://www.wrap.org.uk/sites/files/wrap/Residual\%20Biogas\%20Potential.pdf/ (Accessed on $5^{\text {th }}$ August).

Walker, L. P. and Wilson, D. B. (1991), Enzymatic hydrolysis of cellulose: An overview, Bioresource technology, vol. 36, no. 1, pp. 3-14. 